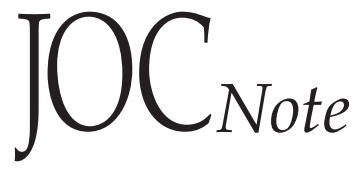

\section{Polymeric Phosphine Ligand from Ring-Opening Metathesis Polymerization of a Norbornene Derivative. Applications in the Heck, Sonogashira, and Negishi Reactions}

\author{
Yun-Chin Yang ${ }^{\dagger, \|}$ and Tien-Yau Luh*,t,,,ll \\ Department of Chemistry and Institute of Polymer Science \\ and Engineering, National Taiwan University, Taipe, \\ Taiwan 106, and Institute of Chemistry, Academia Sinica, \\ Nangang, Taipei, Taiwan 115
}

tyluh@chem.sinica.edu.tw

Received September 7, 2003

\begin{abstract}
The phosphine-containing polymer $\mathbf{1}$ is obtained by ruthenium-catalyzed ring-opening metathesis polymerization of the norbornene derivative $\mathbf{2}$. Polymer $\mathbf{1}$ is employed as the polymer support in the palladium-catalyzed Heck, Sonogashira, and Negishi reactions, and the corresponding (methoxymethyl phenyl)diphenyl phosphine (6) ligand is used for comparison. The polymer-supported catalysts retain most of their catalytic activities in these coupling reactions in the recycling processes.
\end{abstract}

The use of transition-metal catalysts immobilized on polymer supports is well-documented. ${ }^{1}$ Catalysts can in general be recovered by filtration ${ }^{2}$ or by biphasic separation. ${ }^{3}$ Cross-linked styrene-based polymer supports are one of the most popular resins for this purpose. Soluble polymer supports such as those derived from polyethers, ${ }^{4}$ polyacrylates, ${ }^{5}$ polyethylene, ${ }^{6}$ or fluorinated polymers ${ }^{7}$ provide important alternative sources. To the best of our knowledge, phosphine-containing polymer supports arisen from ring-opening metathesis polymerization (ROMP) of norbornene derivatives have been sporadically explored. ${ }^{8}$ It is noteworthy that using such phosphine-containing

\footnotetext{
† Department of Chemistry, National Taiwan University.

₹ Institute of Polymer Science and Engineering, National Taiwan University.

"I nstitute of Chemistry, Academia Sinica.

(1) (a) Bailey, D. C.; Langer, S. H. Chem. Rev. 1981, 81, 110. (b) Leadbeater, N. E.; Marco, M. Chem. Rev. 2002, 102, 3217. (c) Seneci, P. Solid-Phase Synthesis and Combinatorial Techniques; J ohn Wiley: New York, 2001. (d) Burgess, K. Solid-Phase Organic Synthesis; J ohn Wiley: New York, 2000. (e) Pomogailo, A. D. Catalysis by PolymerImmobilized Metal Complexes; Gordon and Breach: Australia, 1998.

(2) (a) Terasawa, M.; Kaneda, K.; Imanaka, T.; Teranishi, S. J. Organomet. Chem. 1978, 162, 403. (b) Parrish, C. A.; Buchwald, S. L. J . Org. Chem. 2001, 66, 3820.

(3) (a) Bergbreiter, D. E. Chem. Rev. 2002, 102, 3345. (b) Bergbreiter, D. E.; Osburn, P. L.; Wilson, A.; Sink, E. M. J . Am. Chem. Soc. 2000, $122,9058$.

(4) (a) Dickerson, T. J .; Reed, N. N.; J anda, K. D. Chem. Rev. 2002 102, 3325. (b) Toy, P. H.; J anda, K. D. Acc. Chem. Res. 2000, 33, 546.

(5) (a) Bergbreiter, D. E.; Osburn, P. L.; Wilson, A.; Sink, E. M. J . Am. Chem. Soc. 2000, 122, 9058. (b) Bergbreiter, D. E.; Osburn, P. L. Smith, T.; Li, C.; Frels, J. D. J. Am. Chem. Soc. 2003, 125, 6254. (c) Bergbreiter, D. E.; Hughes, R.; Besinaiz, J .; Li, C.; Osburn, P. L. J . Am. Chem. Soc. 2003, 125, 8244 3301.

6) Colacot, T. J .; Gore, E. S.; Kuber, A. Organometallics 2002, 21 ,

(7) (a) Horvàth, I. T.; Rábai, J. Science 1994, 266, 72. (b) Horvàth I. T. Acc. Chem. Res. 1998, 31, 641. (c) Schneider, S.; Bannwarth, W. Angew. Chem., Int. Ed. 2000, 39, 4142. (d) J uliette, J .J . J .; Rutherford,
} D.; Horvàth, I. T.; Gladysz, J . A. J . Am. Chem. Soc. 1999, 121, 2696.

\section{SCHEME $1^{\text {a }}$}

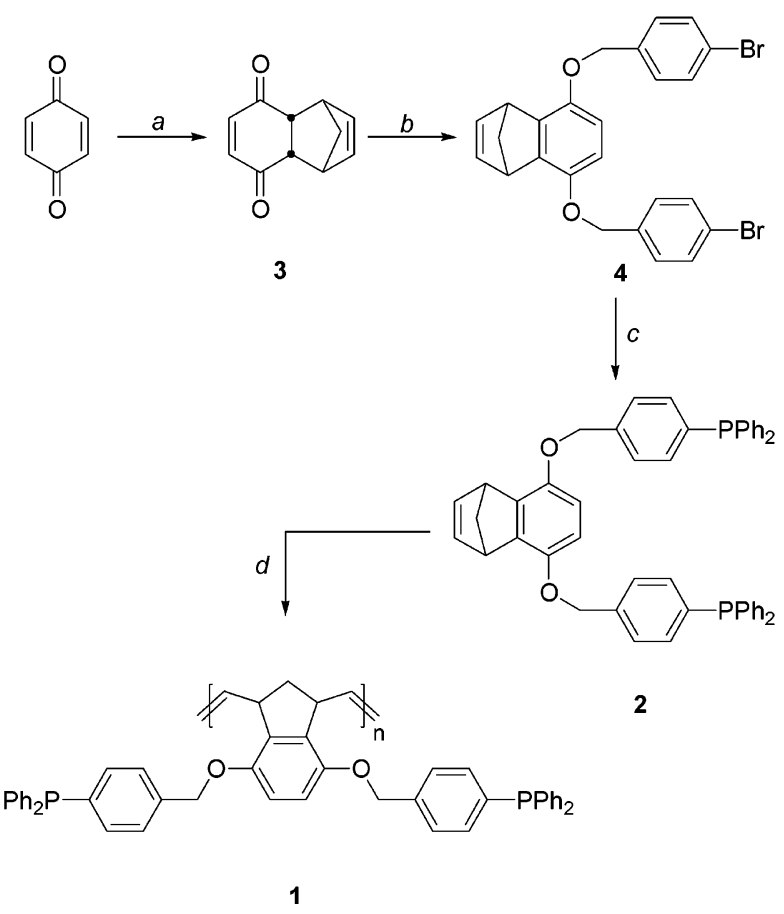

a (a) Cyclopentadiene, $-78{ }^{\circ} \mathrm{C}, 95 \%$. (b) 4-Bromobenzyl bromide, $\mathrm{K}_{2} \mathrm{CO}_{3}$, refluxing $\mathrm{MeCN}, 78 \%$. (c) ${ }^{\mathrm{n}} \mathrm{BuLi},-78{ }^{\circ} \mathrm{C}$, and then $\mathrm{CIPPh}_{2}$, $60 \%$. (d) 5 , rt.

norbornene derivatives would make it more difficult to proceed with the ROMP reaction because the ligand on the catalyst may readily undergo exchange with the phosphine moiety on the substrates, which may reduce the activity of the catalyst. ${ }^{9}$ It is envisaged that the recent highly reactive $\mathrm{N}$-heterocyclic ruthenium carbene cataIyst ${ }^{10}$ may tolerate the presence of the phosphine moiety in the substrates. ${ }^{11}$ We now report the synthesis of the phosphine-containing polymer $\mathbf{1}$ by ROMP of the corresponding monomer $\mathbf{2}$ and the use of $\mathbf{1}$ as the polymersupported ligand in palladium-catalyzed $\mathrm{C}-\mathrm{C}$ bond formation reactions.

Polymer 1 was prepared according to the reaction sequence shown in Scheme 1 . Treatment of $\mathbf{3}$ with $\mathrm{K}_{2^{-}}$ $\mathrm{CO}_{3}$ and 4-bromobenzyl bromide in refluxing $\mathrm{CH}_{3} \mathrm{CN}$ afforded dibromide $\mathbf{4}$ in 78\% yield. Reaction of $\mathbf{4}$ with ${ }^{n} \mathrm{BuLi}$ at $-78^{\circ} \mathrm{C}$ followed by displacement with $\mathrm{CIPPh}_{2}$ gave the monomer $\mathbf{2}$ in $60 \%$ yield. Polymerization of $\mathbf{2}$ using second-generation Grubbs' catalyst $\mathbf{5}^{12}$ in THF at room temperature for $24 \mathrm{~h}$ yielded the corresponding polymer 1. Matrix-assisted laser desorption ionization time of flight (MALDI-TOF) analysis indicated that the polymer may mainly consist of $4-6$ repetitive monomeric

(8) (a) Buchmeiser, M. R.; Wurst, K. J . Am Chem. Soc. 1999, 121, 11101. (b) Pollino, J. M.; Weck, M. Org. Lett. 2002, 4, 753.

(9) Bielawski, C. W.; Grubbs, R. H. Macromolecules 2001, 34, 8838.

(10) (a) Westkamp, T.; Kohl, F. J .; Hieringer, W.; Gleich, D.; Herrmann, W. A. Angew. Chem., Int. Ed. 1999, 38, 2416. (b) Scholl, M.; Trnka, T. M.; Morgan, J . P.; Grubbs, R. H. Tetrahedron Lett. 1999, 40, 2247.

(11) Arstad, E.; Barrett, A. G. M.; Hopkins, B. T.; Köbberling, J . Org. Lett. 2002, 4, 1975.

(12) Mes: 2,4,6-mesitylenyl. dba: dibenzylideneacetone. 
TABLE 1. Use of Phosphine Ligands 1 or 6 in the Palladium-Catalyzed Heck, Sonogashira, and Negishi Reactions

\begin{tabular}{|c|c|c|c|c|c|c|c|c|c|}
\hline \multirow[b]{2}{*}{ cycle } & \multicolumn{3}{|c|}{ Heck reaction } & \multicolumn{3}{|c|}{ Sonogashira reaction } & \multicolumn{3}{|c|}{ Negishi reaction } \\
\hline & $\begin{array}{c}\text { nil } \\
(\%)^{a}\end{array}$ & $\begin{array}{c}6 \\
(\%)\end{array}$ & $\begin{array}{c}1 \\
(\%)\end{array}$ & $\begin{array}{l}\text { nil } \\
\text { (\%) }\end{array}$ & $\begin{array}{c}6 \\
(\%)\end{array}$ & $\begin{array}{c}1 \\
(\%)\end{array}$ & $\begin{array}{l}\text { nil } \\
(\%)\end{array}$ & $\begin{array}{c}6 \\
(\%)\end{array}$ & $\begin{array}{c}1 \\
(\%)\end{array}$ \\
\hline $\begin{array}{l}1 \\
2 \\
3 \\
4 \\
5\end{array}$ & $\begin{array}{r}63 \\
15 \\
0\end{array}$ & $\begin{array}{r}93 \\
30 \\
0\end{array}$ & $\begin{array}{l}95 \\
90 \\
87 \\
82 \\
85\end{array}$ & $\begin{array}{r}42 \\
0\end{array}$ & $\begin{array}{r}93 \\
34 \\
0\end{array}$ & $\begin{array}{l}95 \\
90 \\
86 \\
79 \\
65\end{array}$ & $\begin{array}{r}42 \\
0\end{array}$ & $\begin{array}{r}83 \\
0\end{array}$ & $\begin{array}{r}85 \\
76 \\
47 \\
12 \\
0\end{array}$ \\
\hline
\end{tabular}

units. ${ }^{13}$ 31P NMR of $\mathbf{1}$ and $\mathbf{2}$ appeared as singlets at $\delta$ -5.57 and -5.24 , respectively. Because each of the monomeric units contained two phosphine groups, the loading of the phosphine moiety in $\mathbf{1}$ was therefore fairly high $(2.8 \mathrm{mmol} / \mathrm{g})$. Polymer $\mathbf{1}$ is soluble in moderate polar organic solvents such as THF, toluene, or dichloromethane but insoluble in alkane solvents, ether, and DMF at room temperature. At elevated temperature, a homogeneous solution of $\mathbf{1}$ in DMF was obtained. ${ }^{14}$
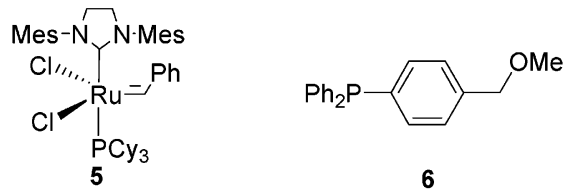

To test the efficacy of $\mathbf{1}$ as a polymer support in catalysis, a series of coupling reactions was examined. 4-(Methoxymethyl phenyl)diphenyl phosphine (6) was also used as a ligand for comparison. In the Heck reaction, a mixture of iodobenzene, methyl acrylate, and $\mathrm{Bu}_{4} \mathrm{NOAC}$ in the presence of $\mathrm{Pd}(\mathrm{OAC})_{2}$ and the phosphine ligand ( 1 or 6) in DMF was heated at $80^{\circ} \mathrm{C}$ for $12 \mathrm{~h}$ (eq 1). After cooling to room temperature, the mixture was filtered, and the solid material was washed with ether, evacuated, and used directly for the next catalytic reaction. The filtrate was worked up as usual to afford the coupling product 7. DMF was chosen as the solvent not only because it is a common solvent for the Heck reaction but also because the polymer ligand $\mathbf{1}$ exhibited different solubilities at different temperatures. The results are summarized in Table 1.

$$
\mathrm{Ph}-\mathrm{I}+=\mathrm{CO}_{2} \mathrm{Me} \underset{\mathbf{1} \text { or } 6}{\stackrel{\mathrm{Pd}(\mathrm{OAC})_{2}}{\longrightarrow}} \mathrm{Ph} \underset{7}{\mathrm{CO}_{2} \mathrm{Me}}(1)
$$

Apparently, the presence of phosphine ligands is essential to give a better yield of $\mathbf{7}$ than those without phosphines. When $\mathbf{6}$ was used, the yield of the reaction dropped from $93 \%$ in the first cycle to $30 \%$ in the second cycle, and no reaction was observed in the third cycle. Presumably, the majority of the palladium catalyst may remain in the DMF solution, and the insoluble portion was barely enough to initiate the second cycle of the Heck reaction. On the other hand, when polymer 1 was

(13) GPC analysis using polystyrene as a ref, however, gave a much lower average molecular weight $\left(\mathrm{M}_{\mathrm{n}}=1000, \mathrm{PDI}=1.1\right)$.

(14) The solubilities of 1 in DMF were $46 \mathrm{mg} / \mathrm{mL}$ at $80^{\circ} \mathrm{C}$ and $<0.7$ $\mathrm{mg} / \mathrm{mL}$ at $25^{\circ} \mathrm{C}$. The solubilities of $\mathbf{1}$ in $\mathrm{Et}_{3} \mathrm{~N}$ were ca. 0.2 and 0.5 $\mathrm{mg} / \mathrm{mL}$ at 25 and $80{ }^{\circ} \mathrm{C}$, respectively. employed, five catalytic cycles had been performed. The catalyst retained more than $90 \%$ of the activity of the catalyst in the previous cycle.

In the Sonogashira reaction, phenylacetylene was treated with methyl 4-iodobenzoate in the presence of $\mathrm{Pd}_{2}(\mathrm{dba})_{3},{ }^{12} \mathrm{Cul}$, and phosphine ligand (1 or $\left.\mathbf{6}\right)$ in refluxing $\mathrm{Et}_{3} \mathrm{~N}$ for $12 \mathrm{~h}$ (eq 2). In a manner similar to that described for the Heck reaction, the mixture was worked up to give $\mathbf{8}$, and the catalyst was recovered for the next cycle. It is noteworthy that $\mathrm{Et}_{3} \mathrm{~N} \mathrm{HI}$ was also precipitated and was mixed with the catalyst for the next cycle. However, the presence of this side product did not show any appreciable effect on the reaction. The results are also outlined in Table 1. Again, the phosphine ligand is indispensable in this reaction. The monomeric ligand $\mathbf{6}$ gave an excellent yield in cycle 1 , but the activity significantly decreased in the second cycle and no reaction was observed in the third cycle. The catalytic activity al so gradually fell by approximately $4-8 \%$ in each recycle experiment when $\mathbf{1}$ was used.

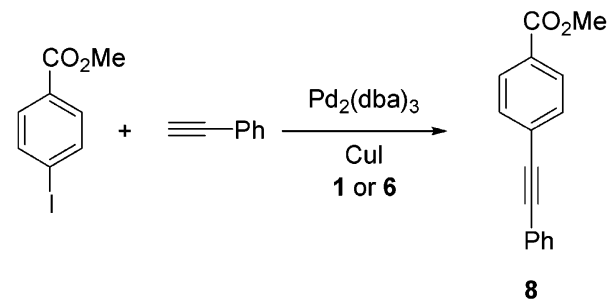

Negishi coupling reaction was also employed to test the activity of the polymer support 1. 4-Cyanophenylzinc bromide was allowed to react with methyl 4-iodobenzoate in the presence of $\mathrm{Pd}(\mathrm{dba})_{2}{ }^{12}$ and phosphine ligand ( $\mathbf{1}$ or 6) in THF at room temperature for $12 \mathrm{~h}$ (eq 3). The mixture was poured into ether, and the precipitate was collected and washed with ether. Usual workup of the filtrate yielded the coupling product $\mathbf{9}$. As can be seen from Table 1, no reaction occurred when the recycled catalyst with monomeric phosphine ligand was used, and the catalytic activity reduced significantly when the recycled polymer-supported catalyst (from 1 ) was employed. As mentioned earlier, polymer $\mathbf{1}$ is readily soluble in THF, which may cause more difficulty in the catalyst recovery.

In summary, we have demonstrated that the phosphine-containing polymer derived from the ROMP of the norbornene derivative can serve as a polymer support for the palladium-catalyzed $\mathrm{C}-\mathrm{C}$ bond formation. Further extension in other applications is in progress in our laboratory.

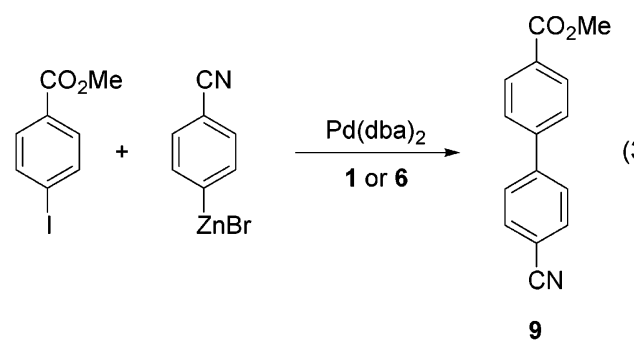

(3)

\section{Experimental Section}

1,4,4a,8a-Tetrahydro-1,4-methanonaphthalene-5,8-dione (3). To a methanol solution $(40 \mathrm{~mL})$ of 1,4-benzoquinone 
(21.62 g, $200 \mathrm{mmol}$ ) was added a methanol $(10 \mathrm{~mL})$ solution of freshly cracked cyclopentadiene $(13.5 \mathrm{~mL}, 200 \mathrm{mmol})$ at $-78^{\circ} \mathrm{C}$. The reaction mixture was gradually warmed to room temperature and stirred for $6 \mathrm{~h}$. Removal of the solvent afforded yellow needles 3 (33.15 g, 95\%). M p: $74-76{ }^{\circ} \mathrm{C}$ (ether, lit. $1^{15} 76-78{ }^{\circ} \mathrm{C}$ ).

5,8-Bis(4-bromobenzyloxy)-1,4-dihydro-1,4-methanonaphthalene (4). A mixture of $\mathbf{3}(1.74 \mathrm{~g}, 10 \mathrm{mmol}), \mathrm{K}_{2} \mathrm{CO}_{3}(8.3$ $\mathrm{g}, 60 \mathrm{mmol}$ ), and 4-bromobenzyl bromide $(5.0 \mathrm{~g}, 20 \mathrm{mmol})$ in $\mathrm{CH}_{3}-$ CN (100 mL) was refluxed for $36 \mathrm{~h}$ under a nitrogen atmosphere. The mixture was quenched with saturated $\mathrm{NH}_{4} \mathrm{Cl}(150 \mathrm{~mL})$, and the organic layer was separated. The aqueous layer was extracted with $\mathrm{CH}_{2} \mathrm{Cl}_{2}(2 \times 100 \mathrm{~mL})$. The combined organic layers were washed with saturated $\mathrm{NaHCO}_{3}(2 \times 400 \mathrm{~mL})$, dried $\left(\mathrm{MgSO}_{4}\right)$, filtered, and evaporated in vacuo. The residue was chromatographed $\left(\mathrm{CH}_{2} \mathrm{Cl}_{2} /\right.$ hexane, 1:4) to give 4 as white needles (4.00 g, 78\%). Mp: $182-183{ }^{\circ} \mathrm{C}(\mathrm{EtOH}) .{ }^{1} \mathrm{H} N M R(400 \mathrm{MHz}$, $\left.\mathrm{CDCl}_{3}\right) \delta: 2.16(\mathrm{~d}, \mathrm{~J}=7.0 \mathrm{~Hz}, 1 \mathrm{H}), 2.21(\mathrm{dt}, \mathrm{J}=7.0,1.6 \mathrm{~Hz}, 1$ $\mathrm{H}), 4.15(\mathrm{dt}, \mathrm{J}=3.6,1.6 \mathrm{~Hz}, 2 \mathrm{H}), 4.96(\mathrm{~s}, 4 \mathrm{H}), 6.48(\mathrm{~s}, 2 \mathrm{H})$, $6.77-6.79(\mathrm{~m}, 2 \mathrm{H}), 7.28$ and $7.50\left(\mathrm{AA}^{\prime} \mathrm{XX}^{\prime}, \mathrm{J}=8.1,0.3,2.1,2.1\right.$ $\mathrm{Hz}, 8 \mathrm{H}) .{ }^{13} \mathrm{C} N M R\left(100 \mathrm{MHz} \mathrm{CDCl}_{3}\right) \delta: 47.1,69.9,70.7,111.8$, 121.6, 129.0, 131.5, 136.6, 141.5, 142.8, 147.9. IR (KBr) v: 3059, $3001,2969,2935,2885,2853,1489,1454,1408,1372,1300$, $1260,1225,1202,1166,1117,1091,1067,1011,978,907,895$, 834, 808, 787, 731, 494, $481 \mathrm{~cm}^{-1}$. MS (FAB) $\mathrm{m} / \mathrm{z}$ (relative intensity): 514 (12), 512 (23), $510\left(\mathrm{M}^{+}, 11\right), 171$ (40), 169 (41), 155 (47), 139 (22), 138 (33), 137 (100), 124 (11), 120 (19), 97 (12), 95 (13), 91 (25), 83 (14), 77 (22), 57 (16). HRMS calcd for $\mathrm{C}_{25} \mathrm{H}_{20} \mathrm{~B}_{\mathrm{r} 2} \mathrm{O}_{2}$ : 509.9830. Found: 509.9824. Anal. Calcd: C, 58.62; $H$, 3.94. Found: C, 58.43; H, 3.77.

5,8-Bis(4-diphenylphosphoranylbenzyloxy)-1,4-dihydro1,4-methanonaphthalene (2). U nder an argon atmosphere, a THF solution $(20 \mathrm{~mL})$ of $4(1.53 \mathrm{~g}, 3 \mathrm{mmol})$ was treated with nBuLi (3.0 mL of a $2.5 \mathrm{M}$ solution, $7.5 \mathrm{mmol}$ ) and stirred at -78 ${ }^{\circ} \mathrm{C}$ for $30 \mathrm{~min}$. A THF solution $(20 \mathrm{~mL})$ of chlorodiphenylphosphine $(1.50 \mathrm{~mL}, 8 \mathrm{mmol})$ was then added to the reaction mixture at $-78^{\circ} \mathrm{C}$. After $1 \mathrm{~h}$, the mixture was gradually warmed to room temperature and stirred for $5 \mathrm{~h}$. The reaction was quenched with saturated $\mathrm{NH}_{4} \mathrm{Cl}(30 \mathrm{~mL})$, and the organic layer was separated. The aqueous layer was extracted with $\mathrm{CH}_{2} \mathrm{Cl}_{2}(3 \times 20 \mathrm{~mL})$. The combined organic extracts were washed with water $(50 \mathrm{~mL})$, dried $\left(\mathrm{MgSO}_{4}\right)$, filtered, and evaporated in vacuo to afford the crude product, which was chromatographed on silica gel $\left(\mathrm{CH}_{2}-\right.$ $\mathrm{Cl}_{2} /$ hexane, $\left.1: 2\right)$ to furnish 2 as white needles $(0.43 \mathrm{~g}, 60 \%)$. Mp: ${ }^{146}-147^{\circ} \mathrm{C}$ (EtOH). ${ }^{1 H} \mathrm{NMR}\left(400 \mathrm{MHz}, \mathrm{CDCl}_{3}\right) \delta: 2.12$ $(\mathrm{dt}, \mathrm{J}=7.0,1.4 \mathrm{~Hz}, 1 \mathrm{H}), 2.17(\mathrm{dt}, \mathrm{J}=7.0,1.6 \mathrm{~Hz}, 1 \mathrm{H}), 4.14$ $(\mathrm{dt}, \mathrm{J}=3.7,1.5 \mathrm{~Hz}, 2 \mathrm{H}), 4.99(\mathrm{~s}, 4 \mathrm{H}), 6.51(\mathrm{~s}, 2 \mathrm{H}), 6.74(\mathrm{t}, \mathrm{J}$ $=1.8 \mathrm{~Hz}, 2 \mathrm{H}), 7.27-7.37(\mathrm{~m}, 28 \mathrm{H}) .{ }^{13} \mathrm{C} \mathrm{NMR}\left(100 \mathrm{MHz} \mathrm{CDCl}_{3}\right)$ $\delta: 47.1,70.0,71.3,112.0,127.4(\mathrm{~d}, \mathrm{~J}=7.2 \mathrm{~Hz}), 128.5(\mathrm{~d}, \mathrm{~J}=$ $6.8 \mathrm{~Hz}), 128.7,133.7(\mathrm{~d}, \mathrm{~J}=19.2 \mathrm{~Hz}), 133.9(\mathrm{~d}, \mathrm{~J}=19.4 \mathrm{~Hz})$, $136.7(\mathrm{~d}, \mathrm{~J}=11.1 \mathrm{~Hz}), 137.1(\mathrm{~d}, \mathrm{~J}=10.7 \mathrm{~Hz}), 138.3,141.5,142.9$, 148.1. 31P NMR (121 MHz, $\left.\mathrm{CDCl}_{3}\right) \delta:-5.24$. IR (KBr) $v: 3068$, $3000,2933,2866,1585,1490,1459,1433,1400,1301,1256$, $1164,1116,1090,1043,1017,908,810,743,696,505 \mathrm{~cm}^{-1} . \mathrm{MS}$ $(F A B) \mathrm{m} / \mathrm{z}$ (relative intensity): $723\left(\mathrm{M}+\mathrm{H}^{+}, 53\right), 722\left(\mathrm{M}^{+}, 40\right)$, 292 (13), 289 (13), 277 (10), 276 (53), 275 (100), 197 (16), 185 (13), 183 (20), 167 (22), 165 (17), 155 (18), 138 (18), 137 (34), 121 (17), 107 (10). HRMS calcd for $\mathrm{C}_{49} \mathrm{H}_{41} \mathrm{O}_{2} \mathrm{P}_{2}\left(\mathrm{M}+\mathrm{H}^{+}\right)$: 723.2599. Found: 723.2582. Anal. Calcd for $\mathrm{C}_{49} \mathrm{H}_{40} \mathrm{O}_{2} \mathrm{P}_{2}$ : C, 81.42; H, 5.58. Found: C, 81.17; H, 5.45 .

Synthesis of Polymer 1. In a glovebox, to a THF solution ( $5 \mathrm{~mL}$ ) of $\mathbf{3}$ (361 mg, $0.5 \mathrm{mmol}$ ) was added $\mathbf{5}$ (21 mg, $0.025 \mathrm{mmol}$ ), and the mixture was stirred at room temperature for $24 \mathrm{~h}$ and then poured into pentane $(50 \mathrm{~mL})$ to form a pink suspension. The suspension was centrifuged, and the pink precipitate was collected. The precipitate was dissolved in $2 \mathrm{~mL}$ of $\mathrm{CH}_{2} \mathrm{Cl}_{2}$ and reprecipitated in pentane $(20 \mathrm{~mL})$ before centrifuging. The reprecipitation was repeated a few times to provide $\mathbf{1}$ as a pale yellowish white powder (325 mg, 90\%). ${ }^{1} \mathrm{H}$ NMR (400 M Hz, $\left.\mathrm{CDCl}_{3}\right) \delta:$ 1.25-1.85 (br, $\left.1 \mathrm{H}\right), 2.15-2.75(\mathrm{br}, 1 \mathrm{H}), 3.45-4.45(\mathrm{br}$, $2 \mathrm{H}), 4.45-5.15(\mathrm{br}, 4 \mathrm{H}), 5.28-5.90(\mathrm{br}, 2 \mathrm{H}), 6.00-6.50(\mathrm{br}, 2 \mathrm{H})$, 6.60-7.80 (br, 28H). ${ }^{31} \mathrm{P}$ NMR (121 $\left.\mathrm{MHz}^{\mathrm{C}} \mathrm{CDCl}_{3}\right) \delta$ : $-5.57 . \mathrm{IR}$ $(\mathrm{KBr}) v: 2959,2919,1488,1456,1434,1398,1379,1260,1184$,

(15) Marchand, A. P.; Allen, R. W. J . Org. Chem. 1974, 39, 1596.
1017, 806, 743, 694, $539 \mathrm{~cm}^{-1}$. MALDI-TOF MS (dithranol) m/z (relative intensity): 2356 (53), 3110 (100), 3865 (77), 4619 (23), 5373 (6), 6128 (3).

(4-Methoxymethylphenyl)diphenylphosphane (6). Under an argon atmosphere, a THF solution (20 mL) of 1-bromo-4methoxymethylbenzene $(4.02 \mathrm{~g}, 20 \mathrm{mmol})$ was treated with $\mathrm{n}_{\text {- }}$ BuLi ( $10 \mathrm{~mL}$ of a $2.5 \mathrm{M}$ solution, $25 \mathrm{mmol}$ ) at $-78{ }^{\circ} \mathrm{C}$, and the mixture was stirred for $30 \mathrm{~min}$. A THF solution $(10 \mathrm{~mL})$ of chlorodiphenylphosphine $(5.40 \mathrm{~mL}, 30 \mathrm{mmol})$ was then introduced at $-78^{\circ} \mathrm{C}$. After $1 \mathrm{~h}$, the mixture was gradually warmed to room temperature, stirred for $5 \mathrm{~h}$, and quenched with saturated $\mathrm{NH}_{4} \mathrm{Cl}(30 \mathrm{~mL})$. The organic layer was separated, and the aqueous layer was extracted with $\mathrm{Et}_{2} \mathrm{O}(3 \times 20 \mathrm{~mL})$. The combined organic extracts were washed with water $(50 \mathrm{~mL})$, dried $\left(\mathrm{MgSO}_{4}\right)$, filtered, and evaporated in vacuo to afford the crude product, which was chromatographed on silica gel (hexane/ $\left.\mathrm{CH}_{2} \mathrm{Cl}_{2}, 1: 4\right)$ to give 6 as a colorless oil (5.58 g, 91\%). ${ }^{1 \mathrm{H}} \mathrm{NMR}$ $\left(400 \mathrm{MHz} \mathrm{CDCl}_{3}\right) \delta: 3.40(\mathrm{~s}, 3 \mathrm{H}), 4.45(\mathrm{~s}, 2 \mathrm{H}), 7.26-7.35(\mathrm{~m}$, $14 \mathrm{H}) .{ }^{13} \mathrm{C}$ NMR $\left(100 \mathrm{MHz} \mathrm{CDCl}_{3}\right) \delta: 58.2,74.3,127.7(\mathrm{~d}, \mathrm{~J}=$ $7.1 \mathrm{~Hz}), 128.4(\mathrm{~d}, \mathrm{~J}=6.9 \mathrm{~Hz}), 128.6,133.8(\mathrm{~d}, \mathrm{~J}=19.1 \mathrm{~Hz})$, $133.9(\mathrm{~d}, \mathrm{~J}=19.4 \mathrm{~Hz}), 136.4(\mathrm{~d}, \mathrm{~J}=10.5 \mathrm{~Hz}), 137.1(\mathrm{~d}, \mathrm{~J}=10.5$

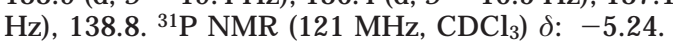

Heck Reaction. A DMF suspension (10 mL) of tetrabutylammonium acetate $(0.75 \mathrm{~g}, 2.5 \mathrm{mmol})$ and crushed $4 \mathrm{~A}$ mol ecular sieve $(0.4 \mathrm{~g})$ was stirred for $15 \mathrm{~min}$. Phosphine $\mathbf{1}$ ( $36.1 \mathrm{mg}, 0.05$ $\mathrm{mmol})$, iodobenzene $(0.11 \mathrm{~mL}, 1.0 \mathrm{mmol})$, and methyl acrylate $(0.18 \mathrm{~mL}, 2 \mathrm{mmol})$ were then successively added to the mixture, and the mixture were stirred for another $15 \mathrm{~min}$ before addition of palladium acetate $(11.2 \mathrm{mg}, 0.05 \mathrm{mmol})$. The reaction mixture was stirred at $80^{\circ} \mathrm{C}$ for $12 \mathrm{~h}$ and then filtered on filter paper. The insoluble materials were washed with $\mathrm{Et}_{2} \mathrm{O}(50 \mathrm{~mL})$ and collected for subsequent runs. The filtrate was extracted with water $(50 \mathrm{~mL})$. The aqueous layer was extracted with $\mathrm{Et}_{2} \mathrm{O}(3$ $\times 50 \mathrm{~mL}$ ). The combined organic extracts were washed with saturated $\mathrm{NH}_{4} \mathrm{Cl}(50 \mathrm{~mL})$, dried $\left(\mathrm{MgSO}_{4}\right)$, filtered, and evaporated in vacuo to afford the crude product. The crude product was purified by flash column chromatography $\left(\mathrm{CH}_{2} \mathrm{Cl}_{2} /\right.$ hexane, 1:4) and recrystallized from ethanol to provide $\mathbf{7}$ as a white solid (0.15 g, 95\%). Mp: $34-35^{\circ} \mathrm{C}$ (lit. $.^{16} 35-36{ }^{\circ} \mathrm{C}$ ).

A similar procedure was employed when phosphine 6 was used.

Sonogashira Reaction. To methyl 4-iodobenzoate (262 mg, $1.0 \mathrm{mmol})$ in $\mathrm{Et}_{3} \mathrm{~N}(10 \mathrm{~mL})$ was added $\mathrm{Pd}_{2}(\mathrm{dba})_{3} \cdot \mathrm{CHCl}_{3}(26 \mathrm{mg}$, $0.025 \mathrm{mmol}$ ) and phosphine $\mathbf{1}(36.1 \mathrm{mg}, 0.10 \mathrm{mmol}$ ). The reaction mixture was bubbled with nitrogen for $10 \mathrm{~min}$ followed by the addition of phenylacetylene $(0.11 \mathrm{~mL}, 1.1 \mathrm{mmol})$ and Cul $(4.8$ $\mathrm{mg}, 0.025 \mathrm{mmol}$ ). The mixture was refluxed for $12 \mathrm{~h}$. After cooling to room temperature, the mixture was filtered on filter paper. The insoluble materials were washed with $\mathrm{Et}_{2} \mathrm{O}(50 \mathrm{~mL})$ and collected for subsequent runs. The filtrate was added to a saturated $\mathrm{NH}_{4} \mathrm{Cl}$ solution $(50 \mathrm{~mL})$, and the organic layer was separated. The organic layer was washed with saturated $\mathrm{NH}_{4^{-}}$ $\mathrm{Cl}(3 \times 50 \mathrm{~mL})$, dried $\left(\mathrm{MgSO}_{4}\right)$, filtered, and evaporated in vacuo to afford the crude product, which was chromatographed on silica gel $\left(\mathrm{CH}_{2} \mathrm{Cl}_{2} /\right.$ hexane, $\left.1: 4\right)$ to give 8 as a white solid $(0.22 \mathrm{~g}, 95 \%)$. Mp: $120-121^{\circ} \mathrm{C}$ (EtOH, lit. $17124^{\circ} \mathrm{C}$ ).

A similar procedure was employed when phosphine 6 was used.

Negishi Reaction. 4-Bromobenzonitrile (457.4 mg, $1.2 \mathrm{mmol}$ ) in THF $(10 \mathrm{~mL})$ was treated with ${ }^{n} \mathrm{BuLi}(0.5 \mathrm{~mL}$ of a $2.5 \mathrm{M}$ solution, $1.25 \mathrm{mmol}$ ) at $-78{ }^{\circ} \mathrm{C}$ for $30 \mathrm{~min}$. $\mathrm{ZnBr}_{2}(292 \mathrm{mg}, 1.3$ $\mathrm{mmol})$ in THF $(5 \mathrm{~mL})$ was then added at $-78^{\circ} \mathrm{C}$, and after being stirred for $5 \mathrm{~min}$, the mixture was slowly warmed to $0{ }^{\circ} \mathrm{C}$ and then transferred via a cannula to another flask containing Pd$(\mathrm{dba})_{2}(23 \mathrm{mg}, 0.04 \mathrm{mmol})$, phosphine 1 (57.8 $\left.\mathrm{mg}, 0.08 \mathrm{mmol}\right)$, and methyl 4-iodobenzoate (262 mg, $1.0 \mathrm{mmol})$ in THF $(10 \mathrm{~mL})$. The mixture was then warmed to room temperature and stirred for $12 \mathrm{~h}$. $\mathrm{Et}_{2} \mathrm{O}(50 \mathrm{~mL})$ was added, and the mixture was filtered on filter paper. The insoluble materials were washed with $\mathrm{Et}_{2} \mathrm{O}$ $(50 \mathrm{~mL})$ and collected for subsequent runs. The filtrate was extracted with saturated $\mathrm{NH}_{4} \mathrm{Cl}(3 \times 100 \mathrm{~mL})$, dried $\left(\mathrm{MgSO}_{4}\right)$,

(16) Inoue, T.; Tsutsumi, S. J . Am. Chem. Soc. 1965, 87, 3525.

(17) Drefahl, G.; Ploetner, G. Chem. Ber. 1960, 93, 990. 
filtered, and evaporated in vacuo to afford the crude product, which was chromatographed on silica gel $\left(\mathrm{CH}_{2} \mathrm{Cl}_{2} /\right.$ hexane, 1:1) to give 9 as a white solid $(0.20 \mathrm{~g}, 85 \%)$. Mp: $104-105^{\circ} \mathrm{C}$ (EtOH, lit. $\left.{ }^{18} 102-103^{\circ} \mathrm{C}\right)$.

(18) Ananthakrishnanadar, P.; Kanan, N. J . Chem. Soc., Perkin Trans. 2 1984, 1, 35.
A similar procedure was employed when phosphine $\mathbf{6}$ was used.

Acknowledgment. We thank the National Science Council and the Ministry of Education of the Republic of China for financial support.

J $0035318 Z$ 